\title{
Cutting through the shame
}

CMAJ Podcasts: article reading at https://soundcloud.com/cmajpodcasts/160119-hum

I was an undergraduate student in psychology and seemingly had it all together; at least that's what others thought. Like an iceberg, there was plenty below my surface. I was haunted by painful memories. From the time I was nine, I had been sexually, physically and verbally abused. I recall being bullied as a young adolescent. I remember the constant throbbing in my arms from being hit. Worse than any strike, however, were the words I was tormented with on almost a daily basis: I was worthless, weak and pathetic; I would be better off taking my own life. The more I heard these words, the more I believed them. After a while, I looked in the mirror and despised the person staring back. Like many young men, I was steadfast in my attempt to mask emotional pain. I blamed myself for how others had treated me. I thought there was something inherently wrong with me for "letting" it happen and that I somehow deserved it.

Over time, my efforts to conceal my inner pain took a toll and manifested into bouts of depression, each one becoming more and more severe. As any person in my condition would, I desperately sought relief, even if it was short-lived. For me, relief came through cutting myself with razor blades and other sharp objects. I was 15 when I cut myself for the first time. I was in my basement, alone and feeling distraught. I saw a box cutter and, without thinking, grabbed it and slowly scraped it against the skin of the outside of my hand. I don't know why I did it. Seeing the rawness of my broken skin inexplicably provided a sense of relief. It helped me "see" the awfulness I felt inside — an awfulness for which I had no words.

As irrational as it may seem, cutting became logical. It was the only way I knew to quell the storm brewing inside. The more I cut, the more selfinjury seemed to take on a life of its own. I began to lose a sense of who I

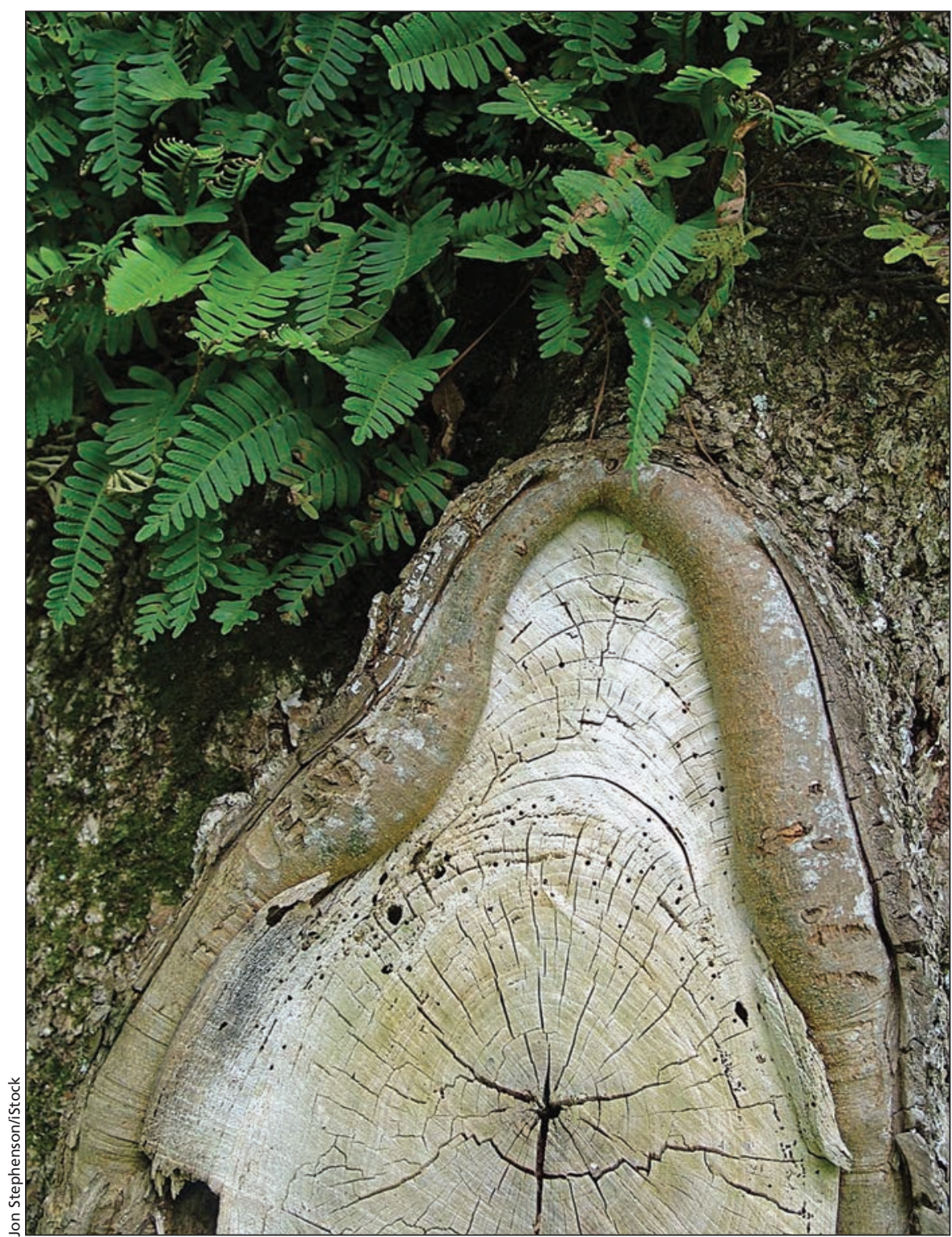

was and where my life was going. My thoughts were marred by self-abhorrent messages, urges to harm myself and a belief that I was destined to feel the way I did. Hope became remote.

Today my body is covered in scars; they represent a narrative of past despair that I carry with me everywhere I go. Although I cannot recall the precise event or story leading to every scar, memories behind others are hard to forget. One set of scars on my left forearm is especially prominent and corresponds to a particularly difficult night in my life.

I was 20 at the time and in the midst of my undergraduate degree. Living away from home, I had been depressed for most of the academic year. Nighttime was especially difficult. Depression made it impossible to sleep and not dwell on the past. I was sitting alone at my desk in my one-bedroom apartment. The only light came from my computer screen, which I stared at blankly. The darkness, 
like it so often did, elicited painfully vivid flashbacks. I saw a younger but forlorn version of myself: scared, crying and screaming "Please stop!" The image played over and over again. With it came a barrage of messages: "you're worthless" ... "you're nothing" ... "you're weak and pathetic." The messages, like my despair, became progressively more intense with each passing moment. I felt I was suffocating. My vision became increasingly tunnelled.

In what had become a habitual response to unbearable emotional pain, I reached for a razor blade - one of many I kept on hand. Without hesitat- about the reactions my injuries would elicit from family, friends and professionals. What would others think of me? Would they judge me? What if they saw me in the same abysmal light that I saw myself? I was further silenced by my own self-directed stigma, the culmination of which was a not-so-fine blend of isolation, agony, emptiness and hopelessness.

If only someone at that time had seen the inelegant marks and scars covering my arms, and parts of my legs and torso. My body was a canvas for emotional pain, but one hidden behind a veil of long sleeves, long pants and myriad explanations that I conveyed with a

\section{I was terrified about the reactions my injuries would elicit from family, friends and professionals.}

ing, I firmly pressed the blade to my forearm and began to move it steadily across my skin over and over again. My eyes welling with tears, I looked down at my arm - my visual field a crimson blur. I squeezed my eyes tightly, allowing tears to roll down my cheeks. The sight and the sharp sensation that cutting provided gradually allowed my vision to become less attenuated. The waves of despair started to calm, and the maelstrom began to subside - at least for a moment. Cutting had never let me down. Once again, it provided respite from what was intolerable misery.

Beyond the relief it provided, cutting allowed me to convey and visualize the mental anguish and self-loathing I felt inside. The marks left on my body represented and validated the pain I thought I deserved. At the same time, cutting silenced me: it engendered a profound sense of shame for inflicting such harm on my own body. I firmly believed no one could ever comprehend why I did it and that others would deem the act irrational. I felt utterly alone. I was terrified feeble sense of conviction. It was a feigned attempt at normalcy.

Not surprisingly, my situation worsened. Despite the momentary relief cutting provided, the more I cut, the more depressed I became and, in turn, the more hopeless I was about recovery. It was a never-ending cycle. Before I knew it, I was suicidal and even took actions to end my life.

I used to wonder what life would have been like had I never self-injured; had I not experienced trauma, been depressed or almost taken my own life. Venturing into the unknown, albeit the impossible, is a futile endeavour. Although I would never wish these experiences on anyone - even those who wronged me - I have learned to accept them. Hardship and mental illness served as catalysts for dormant capacities to surface. In this regard, I believe I am wiser, more resilient, more compassionate, more determined to overcome obstacles and more appreciative of what life has to offer. I have learned to embrace the smallest moments of joy, never taking them for granted. I believe my suffering has led me to be more insightful in my work and understanding of who I am as a person. I feel compassion for people who are struggling as I once did, and I have cultivated this into a commitment to help them. This has helped to fuel my work.

No one experience or set of experiences defines an individual. Self-injury has never defined me. I was and am not a "self-injurer" or "cutter." These are descriptors that label and, at times, pathologize people by reducing them to a behaviour. The residual scarring I bear on my body does not represent the person I am. Rather, my scars are symbolic of inner fortitude and serve as an aidemémoire, telling me I made it. At a time when I had no voice, and no way to allay the tumultuous storm of emotions I felt each day, self-injury made sense. As much as I was ostensibly destroying myself, cutting served to save my life.

By no means do I promote or endorse self-injury as a way to cope or express emotional pain. It is what I had at the time, and what countless others have at their immediate (and often desperate) disposal. For me, cutting was a rational response during an irrational period of my life. Ultimately, what I learned through my experience makes me the person I am today - a person I accept without shame.

\section{Stephen P. Lewis PhD}

Associate professor in psychology, Department of Psychology, University of Guelph, Guelph, Ont.

This article has been peer reviewed.

This is the author's story.

CMAJ 2016. DOI:10.1503/cmaj.160119

"Wherever the art of medicine is loved, there is also a love of Humanities." - Hippocrates 